\title{
A TUDÓSVÁLLALATOK ÉRTÉKELÉSI SAJÁTOSSÁGAI
}

„Navigare necesse est ...” - „Hajózni szükséges ...

A vállalatok értékelése különösen a gyorsan változó, képlékeny ágazatokban, esetenként bizonytalan kimenetelű kutatások és fejlesztések során igazi intellektuális kihívás. A társadalmi felelősség, etika és egyéb faktorok egyenesen misztikusnak tűnhetnek a hagyományos módszertani alapok talaján. A szerző dolgozatának fókuszában a vállalati értékmodell újragondolása áll, és az írás a jelenséget pénzügyi oldalról közelíti meg.

A tudósvállalat azon új típusú szerveződés speciális, magyar változata, mely tudásvállalatként vonult be a szakirodalomba. A kis „ó” betűben alakot öltő apró eltérésen azonban túlzás nélkül egy civilizáció nyugszik, elég csak a számítógépre gondolnunk.

Ma ezt a pici különbséget magyar kreativitásként jegyzik világszerte, köszönhetően azon tudósnemzedék tagjainak, akik marslakóként élnek, elsősorban az atlanti térség, a tengerentúli elit tudatában. Csodálatra méltó szellemi tőkével bírtak, mely jól ismert történelmi okok miatt döntően „Nyugaton” fejtette ki áldásos tevékenységét. Teller Ede, Szilárd Leó, Neumann János csak néhány név a legnagyobbak közül.

A XX. század hajnalán Európa vérkeringésébe ismét bekapcsolódó, modernizálódó magyar gazdaság európai, világszínvonalú adaptációra volt képes. Ma a tudásintenzív iparágak hazai teljesítményében, potenciáljában, jóllehet gyökeresen eltérő környezeti feltételekbe ágyazva, hasonló tendenciák bontakoznak ki.

Rendkívül izgalmas, intellektuális kihívás és egyben nemes feladat azon feltörekvő, innovatív vállalkozások, ötletek megvalósulását elősegíteni, melyek az új gazdaság hazai és nemzetközi zászlóshajóivá válhatnak. Szellemi bázisát tekintve az esély adott. Modern vállalatvezetési ismeretek és pénzügyi technológiák nélkül azonban jobb esetben is csak halászbárkákról beszélhetünk, melyek zászlóbontás után átmeneti- leg hazai vizeken maradnak, de esélyük sem nyílik eljutni európai tengerekre, globális óceánokra.

Visszaevezve a gazdálkodástudomány látszólag sekélyebb vizeire, jelen dolgozat azon vállalatértékelési kihívásokra, új dimenziókra fókuszál, melyek nélkül a jelentős humán tôkével, immateriális vagyonnal és túlnyomórészt információs folyamatokkal működő vállalatok értéke nem ölt valós tartalmat. A tudásintenzív vállalatok értékteremtő faktorai speciális, újszerű értékelési eljárásokat igényelnek. A mai környezeti feltételek elsősorban a vállalati- és pénzügyi stratégia rugalmasságát, valamint ma még nehezen kvantifikálható dimenziók vizsgálatát igénylik. A stratégia és a finanszírozási megoldás külön-külön és együttesen is hozzáadott értéket teremt ezen új típusú vállalatok körében. A vállalatok értékelése pedig különösen a gyorsan változó, képlékeny ágazatokban, esetenként bizonytalan kimenetelű kutatások és fejlesztések során igazi intellektuális kihívás. A társadalmi felelősség, etika és egyéb faktorok pedig egyenesen misztikusnak tűnhetnek a hagyományos módszertani alapok talaján. Jelen dolgozat fókuszában a vállalati értékmodell újragondolása áll. Az olvasó által kézben tartott írás a jelenség pénzügyi oldalról való megközelítése ${ }^{1}$.

A 90’-es évek derekán felerősödő világméretű, elsősorban angolszász-orientált, internetre alapozott technológiai befektetési láz a tőkepiaci buborék(ok) 
kipukkadásával mára lecsillapodott. A befektetők mohósága miután előbb félelembe csapott át, és a kissé eltúlzott óvatosság atmoszférája következtében több iparág pangott a tőkehiánytól, ugyanakkor más területeken konszolidáció zajlott le 2000-2003 között. A történések kapcsán felerősödtek a kritikai hangok. Ezek szerint továbbra sem beszélhetünk „Új Gazdaságról”, melynek törvényszerűségei az információs világ technológiai-piaci-társadalmi összetevőin nyugszanak, és alapvetően különböznek a korábbi gazdaságot leíró közgazdasági összefüggésektől. Jelen dolgozat nem kívánja leírni és elemezni az új gazdaság jelenségét, pusztán arra szorítkozik, hogy a teljesség igénye nélkül utaljon néhány, a tárgyalt téma szempontjából is alapvető trendre.

- Az USA informatikai ágazata a '90-es évek derekán 780 milliárd dolláros forgalmával megelőzte a korábban vezető autó- és építőipart ${ }^{2}$. Francesco Daveri, a Parmai Egyetem és Guido Tabellini, a milánói Bocconi Egyetem közgazdaságtan-professzorai tanulmányukban bemutatták, hogy az Egyesült Államok gazdasága mély szerkezeti átalakuláson ment keresztül az elmúlt évtized második felében, dacára a technológiai lufinak. Az 1990-1995 közötti termelékenység évi $1 \%$-ról a kilencvenes évek következő öt évében 2\%-ra, 2001-2002-ben 3\%-ra gyorsult. A termelékenységjavulásban az új információs technológiák hatása mintegy $80 \%$-ban érhető tetten, és ekkor még nem számoltak az elért műszaki haladás eredményeinek elkövetkezendő években történő használatbavételével, mely alapján a hatékonyság növekedése tartós jelenségnek bizonyul ${ }^{3}$.

- A tudomány/technológia üzleti környezettel való egyre szorosabb kapcsolata alapvetóen meghatározza napjaink és a jövő gazdasági életét. A tercier szektorban dolgozók aránya már régóta jelentősen meghaladja az iparban foglalkoztatottak számát a fejlett országokban. Egy amerikai munkaügyi statisztika prognózisa szerint 2005-re a teljes foglalkoztatottakon belül az iparban dolgozók aránya $20 \%$ alá süllyed ${ }^{4}$. Ma a kutatás-fejlesztés-oktatás, az ún. kvaterner szektor látványos bővülésének lehetünk tanúi. Ennek keretében múködik az üzleti élet az oktatás és a tudományos kutatás virágzó kapcsolatrendszere világszerte. Európa új típusú fellegvárai, mint Finnország, Svédország, Írország, kiugró teljesítményt és növekedési ütemet értek el az elmúlt néhány év során.

- A munkaerőpiac a technológia ${ }^{5}$ szédületes tempójú fejlődése mellett, kihívások sorával néz szembe. Egyfelől rohamosan növekszik a jól fizető szakér- tői, tanácsadói állások száma és egyre inkább keresetté válnak a komplex folyamatokat kezelni tudó, az információkat rendszerbe foglaló, azokat elemezni és használni tudó szakemberek. A tendencia természetesen érinti a hagyományos ipari és szolgáltató vállalatokat is, ahol szintén növekszik az információval foglalkozó munkatársak aránya. Az innovatív vállalkozások létrejöttének pedig egyik feltétele egyrészt az igen magas szintű szaktudás, melyre a tevékenység ráépül, másrészt az üzlet modellezésére képes, annak pénzügyi, jogi, informatikai aspektusait egyaránt átlátó és kezelő menedzsment.

Másfelől a fenti elvárásoknak megfelelni tudó munkavállalók száma nem tud lépés tartani a gyorsuló ütemben növekvő igényekkel. Ebből következően a társadalom is erôs polarizálódásnak van kitéve, melynek eredményeképpen egy kisebb, magasan képzett elit szegmens és egy nagyobb, elmaradó réteg kialakulása körvonalazódik.

Ebből következően megnőtt a tehetségek felkutatásának, megnyerésének és megtartásának jelentősége. Egyfajta versengés indult meg a vezető vállalatok körében, mely szintén megerősíti a szellemi tőke, mint legfőbb versenyelőny forrás abszolút elsőbbségét a többi termelési tényezővel szemben. Kiemelt szempont, hogy magasan képzett munkatárs a vállalaton belül maradjon, és nomád vándor módjára ne álljon tovább, ne vigye magával a megszerzett, adott esetben vállalatspecifikus tudást is.

Mindebból logikusan következik az ember/családbarát munkahely egykor álomnak tűnő valósága, a vállalatok társadalmi és környezeti felelősségének felerősödésével egyetemben.

Új értékhordozók jelentek meg tehát, melyek által megnyerhető és megtartható az egyre inkább társadalom- és környezettudatos egyén, munkavállaló vagy éppen vevő formájában.

\section{Változékonyság}

Különösen a nagy kockázatú kutatások - pl. gyógyszerfejlesztés - területén találkozhatunk minden befektető „rémálmával”, a nagy tőkeigényű, bizonytalan időtartamú és kimenetelû́ $\mathrm{K}+\mathrm{F}$ projektekkel, melyek ugyanakkor rendkívüli hozamokkal is kecsegtetnek. Hasonló tevékenységnek számít a szoftverfejlesztés is, jóllehet talán egzaktabb, és valamivel rövidebb átfutatási időt igényel. Ugyanakkor a fejlesztés irányainak meghatározása, az üzleti stratégia helyes megválasztá- 
sa nagyon fontos, mert hiába készül kifinomult szoftvertermék, ha a technológiai fóárama nem az előrejelzettnek megfelelően alakul. Ez pedig a mai változékony, komplex, globális, gazdasági környezetben valós veszélyeket rejt magában. Kockázati faktornak számítanak a különböző információtechnológiai standardok, valamint a hardver- és szoftveripar kölcsönhatása által generált folyamatos változások, melyeknek gyorsaságát a potenciális fogyasztói társadalom üzleti szempontból kritikus tömegnek tekintett hányada sem képes követni. Így fordulhat elő, hogy még meg sem jelent igényekre, egy-egy vállalat túl korán szállít kész megoldásokat. Ügyelni kell azonban a beruházási javaslatok kölcsönhatásaira is például6:

- különböző élettartamú beruházások közötti választás,

- meglévő eszközök cseréje,

- kihasználatlan kapacitás költségei,

- változó kapacitáskihasználás,

- egymást kölcsönösen kizáró projektek.

A korai szakaszukban (seed, early stage) lévő tudásalapú vállalatok legfóbb jellemzóit az 1. táblázat szemléleti.

1. táblázat

A tudásalapú vállalatok jellemzői

\begin{tabular}{|l|l|}
\hline Adottságok & Kritikus tényezők (kockázatok) \\
\hline $\begin{array}{l}\text { Szellemi tőke, piacon hasz- } \\
\text { nosítható szaktudás }\end{array}$ & Projekt kimenete \\
\hline $\begin{array}{l}\text { Egyedi technológia/eljárás, } \\
\text { termék/szolgáltatás }\end{array}$ & Projekt időszükséglete \\
\hline Valószínűsített piacméret & Növekedési ütem \\
\hline Kezdeti infrastruktúra & $\begin{array}{l}\text { Menedzsment: finanszírozási } \\
\text { megoldás és stratégiaalkotás, } \\
\text { stratégiai szövetségek }\end{array}$ \\
\hline
\end{tabular}

A pénzáramlás-előrejelzések forgatókönyv-készítésre (szcenárió elemzés) alapozhatók, mellyel előre jelezhető az eredmény alakulása.

\section{Kreativitás}

„Arra a magyar szellemi tókére épitettünk,
amely a viszonylag magas szintü
matematikaoktatás és kultúra révén rendkívül sok
kiváló számítógépes szakembert termelt...7 (Bojár Gábor)

A vállalat fizikai alakot nem öltő, immateriális eszközeinek legnagyobb súlya egyre inkább a koponyákban összpontosul, illetve „tárgyiasult” formában szellemi alkotásként, szabadalomként, találmányként, védjegyként, márkaként, vagyoni értékű jogként stb. szerepel a társaságok mérlegében. Hagyományos profilú cégek esetében is megfigyelhető ilyen tendencia, a költségszerkezet, a vállalati folyamatok és munkaszervezés terén egyaránt.

A fentebb említett, mérlegtételként is megjelenő vagyonelemek azonban nem tartalmazzák egzakt formában a szellemi hozzáadott értéket. Nem állíthatjuk, hogy pusztán statisztikai módszerekkel vagy modellezési eljárásokkal tervezett éves árbevétel egy főre jutó összegéből kiindulva nagy pontossággal meg tudjuk határozni jövendő munkatársunk javadalmazását/költségét. A vállalat értékének emelése több ilyen szervezeti tag együttes munkájának eredménye, akik szakmai tudásuk révén kellő együttmúködési hajlammal megáldva szinergiahatásokat is generálnak ötletbörzék alkalmával, szervezett fórumokon, informális kapcsolatok útján. Számszerüsíthető-e valamilyen formában, tudjuk-e mérni ezt a hatást? Jelenleg számvitelileg ez a goodwill, azaz üzleti vagy cégérték formájában érhető tetten, illetve tőzsdén jegyzett cégek esetén a piaci kapitalizációban tükröződhet, mely természetesen több más hatást is tartalmaz.

A '90-es évek angolszász javadalmazási, ösztönzési divatjává a különböző tulajdonszerzési megoldások, elsősorban részvényopciók biztosítása vált vezetői szinteken. Ahhoz, hogy egy munkatársat érdekeltté tegyünk a hozzáadott érték generálásában és ezt mérni is tudjuk, javadalmazási opciót kínálhatunk neki. Ugyanezt alkalmazhatjuk mintegy prémium csomagként, a munkacsoport szintjén is elósegítve az együttgondolkodás alkotó légkörét. Tehát az egyén halmozott prémiumban részesül a csoport által generált szinergiahatásoknak megfelelöen. Innen már csak egyetlen lépcsőfok, hogy a teamekböl álló vállalat $K+F$ témáira kötött opciók segitségével jelentös finanszirozási és stratégiai előnyre tegyen szert.

\section{Menedzsmentetika}

„Az Andersen az események hatására még jobb, még erösebb lesz"

(Joe Berardino, egykori vezető partner és vezérigazgató, Arthur Andersen) ${ }^{8}$

A vállalkozás eszközeinek értéke a legtöbb esetben eltér részvényeinek összértékétől. Brealey és Myers ${ }^{9}$ ennek egyik lehetséges okaként a menedzsmentet, mint mérlegen kívüli kötelezettséget említik. A diszkontált pénzáramlás (DCF) értékelési módszer nem tükrözi hủen sem a menedzsment rátermettségi értékét, sem pedig kockázatát, mert nem veszi figyelembe a választás lehetőségének értékét, ti. a vezetés bármikor változtathat döntésein, ha a feltételrendszer változása ezt megkívánja. Túl későn jelez, ha a tendenciák változnak. 
A vezetői érték másik összetevője, annak kockázata: az etikus üzleti magatartás, mely láthatatlan Achillessarokként volt jelen egészen napjainkig. A tőkepiaci értékítélet és a számviteli alapú számítások eltérésének okai között tehát két markáns humánfaktort különíthetünk el: a menedzsment szakmai rátermettségét, ami a vállalat számára egy mérlegen kívüli tételt testesíthet meg, illetve a vezetés magatartásának etikai vonatkozását. Közös vonásuk a nyilvános megmérettetés, tőkepiaci és társadalmi színeken egyaránt. Az elmúlt évtized(ek)ben jellemzően a vállalati kormányzás elvárt szakmai hozzáadott értéke volt a meghatározóbb a piac értékítéletében, azonban több, nem várt esemény hatására az etikai dimenzió is megerősödött. Ebből következően a szakmai teljesítmény elégtelen mivoltát, azaz, hogy jelenértéke kisebb a vártnál vagy negatív, tovább súlyosbíthatja a beszámolók kozmetikázásából, a befektetők megtévesztéséből és megkárosításából, az igazságszolgáltatás akadályoztatásából fakadó negatív megítélés, ami ezen túlmenően peres eljárások lefolytatásában és tetemes kártérítési összegek kifizetésében ölt testet, végső soron tekintélyes társaságok eltűnését eredményezi a világ pénzügyi színpadáról (Arthur Andersen). A pénzügyi jelentések kozmetikázása nem új keletű jelenség. A mai könyvelési csalások azonban drasztikus következményekkel járnak, melyek között csak egy epizód az Enron-Andersen, hiszen méreteinél és tovább gyűrűző hatásinál fogva megújuló hullámokat korbácsol, egyfajta „tisztítóvízzel” árasztva el a piacokat. A globális könyvvizsgáló társaság az egyesült államokbeli Enron vállalat kapcsán vált azon botránysorozat kiinduló pontjává, mely Európában az ír Elan, a német Comroad, a francia Altran és a holland Ahold vállalattal folytatódott ${ }^{10}$. Az Enron-botrány ,utóhatásaként” a JP Morgan Chase-t egymilliárd dolláros leírásra kötelezték, miután tíz másik óriásbankkal együtt fényderült a visszaélések elősegítésében való szerepére ${ }^{11}$. A KPMG 2005-ben 456 millió dollárt volt kénytelen fizetni szabálytalan adóelkerülési tanácsaiért, melyen felül meg kellett szüntetnie a „legmagasabb értékű ügyfelei” számára nyújtott adó-tanácsadási tevékenységét ${ }^{12}$.

Itt az etika olyan feszítő határaihoz értünk, mely komoly gazdasági következményeket okoz már ma és hozhat továbbiakat magával a jövőben ${ }^{13}$. Az erkölcsös magatartás tapinthatóvá vált azon befektetői körök számára is, amelyek eddig csak jogi, filozófiai vagy vallási vonatkozásban találkoztak vele ${ }^{14}$.

Kutató-fejlesztő vállalkozások fentieken kívül akkor is szembesülhetnek a pereskedés tetemes költségés idővonzatával, ha elégtelen jogvédelemben részesülnek szellemi alkotásaik. A jog értékteremtő mivolta nyilvánvalóan meghatározott adott nemzet jogrendszere által. Alkalmazása viszont a vállalatvezetés kompe- tenciája, így további árnyalatát adja az értékelésnek. Ugyanakkor ellene irányuló tisztességtelen piaci magatartás formájában, külső tényezőként ronthatja a vállalat megítélését függetlenül a per későbbi kimenetelétől. $\mathrm{Az}$ alábbi részlet a magyar Graphisoft Rt. 2002-es pénzügyi beszámolójában olvasható:

\begin{abstract}
Peres ügyek - Szerzői jog megsértése 14
2000-ben a Társaság pert indított egyik versenytársa ellen szerzői jogainak megsértése miatt. 2001 decemberében az alperes viszontkeresetet nyújtott be, azt állítva, hogy a Graphisoft tisztességtelen üzleti gyakorlatot folytatott, amiért 605 millió Ft (megközelítóleg 2,4 millió eurót)kártérítést követelt. A vezetés álláspontja szerint az ellenkereset alaptalan, és ezért nem várható, hogy a követelés jelentős hatást gyakorolna a Társaság pénzügyi helyzetére vagy eredményeire.
\end{abstract}

\section{Rugalmassági érték: OPM 16}

Tudásintenzív vállalatok esetében az üzleti tevékenység beruházási-projektekről való döntések folyamatának tekinthető, hiszen nem egy esetben adott vállalat legnagyobb kincséről, kutatási-portfóliójáról beszélünk. A finanszírozási megoldások során a reál/eszközopciók alkalmazásával a kapcsolódó kockázat csökkentése mellett a kutatás-fejlesztési stratégia rugalmasságával egyidejűleg biztosítható. Beruházási döntéshozatalnál a reálopciók klasszikus válfajai a következők ${ }^{17}$ : származékos lehetőségek, kiszállás, időzítés, vállalati termékek vagy termelési módszereik megváltoztatása.

Kutatási feladatok folytatása esetén bármelyiknek meghatározó szerep juthat. A kiszállás például egy eladási opció birtoklását jelenti, melynek értékét a jövőbeni pénzáramlások és binominális módszer segítségével árazhatjuk. Az értékesítés lehetősége megkímélheti a vállalatot attól, hogy további beruházási ráfordításokat tegyen, csak azért, mert már jelentős összeg fekszik eddigi tevékenységben. A projektek reálopciókkal történő értékelését a következő egyszerú példa szemlélteti:

Adott egy gyógyszervegyületek kutatására szakosodott Rt. Az egyik projektjük ötéves időtartamot ölel fel (ez több szakaszra is osztható, az egyszerüség kedvéért most nem bontom több részre). A hatodik évben $200 \mathrm{MFt}$ árbevételt terveznek elérni a kifejlesztett gyógyszer értékesítéséből. Azonban annak valószínűsége, hogy sikerül tartani az ötéves periódust és a piaci versenyhelyzet lehetővé teszi majd ezt az árbevételt, csak $60 \%$. Tehát annak az esélye, hogy nem fejeződik be a kutatás és a piaci bevezetés késedelmet szenved $40 \%$. Ez utóbbi kimenetet a vállalat 
nem engedheti meg magának, mert öt év múlva eszközei (laboratórium stb.) eladására kényszerülne, melyből 40 MFt bevétele származna. Ebben a helyzetben a projekt jelenértéke (PV, Present Value) a következő:

(az elvárt megtérülés ráta legyen most egyszerüen 10\%)

$$
\mathrm{PV}=\frac{0,6 * 200+0,4 * 040}{(1,1)^{5}}=\frac{136}{(1,1)^{5}}=84,5
$$

A menedzsment úgy dönt, megállapodást köt egy multinacionális gyógyszeripari céggel, melynek értelmében öt év elteltével az Rt eldöntheti eladja-e a folyamatban lévő, addig elért kutatási eredményeit 100 MFt-ért. Ekkor a megállapodás egy kiszállási opció, mellyel a megtakarítás: $100-40=60$.

Az opció jövőbeni értéke: $0,4 * 60=24$, jelenértéke pedig: $24=14,9$.

\section{$(1,1)^{5}$}

A projekt jelenértéke tehát a következőképpen módosul:

PV = eredeti projektérték + kiszállási opció értéke = $84,5+14,9=99,4$

A példa felfogható úgy is, hogy a menedzsment hozzáadott értékéről beszélünk, mely a kitűzött stratégia sikeres implementálásában ölt testet. Ennek értéke tehát 14,9 millió Ft-ban mérhető az adott időszakban. A megoldás azt feltételezi, hogy külön mérhető a vezetés és a munkatársak hozzáadott értéke, ami egy kissé erôs megszorításnak tűnik, valamint számvitelileg is nehezen megragadható és elfogadható. Más szemszögból (felvásárlás esetén) a 14,9 millió forint akár a goodwill egy összetevőjének is tekinthető. Az alkalmazott stratégia a beruházási láncolaton kívül piaci együttmúködések, stratégiai szövetségek formájában is tetten érhető, mérhető. Az üzleti kapcsolatok értékelési módszereiről jó áttekintést nyújt Juhász Péter cikke ${ }^{18}$. A költség-, piaci- és jövedelemalapú csoportosításból jellemzően a jövedelemalapú emelhető ki a tudásintenzív vállalkozások esetében. Jelenleg világtrend, hogy a gyógyszerfejlesztés rendkívül hosszú időt ölel fel a kutatásoktól a termék piacra juttatásáig (10-15 év) és ez mellett jelentős finanszírozási kapacitást (800-1000 millió dollár) is feltételez. A nagy gyógyszergyártók a kutatás-fejlesztési szakaszok kiszervezésével igyekeznek gyorsítani a folyamatot, mely a kicsi kutatókat foglalkoztató cégeknek kiváló lehetőséget nyújt stratégiai partnerségre lépni olyan multinacionális partnerekkel, mint a Merck vagy a Pfizer. A kiszervezett tevékenységeken keresztül tehát a kisebb cégek jövedelemhez jutnak, melyből származtatható a kapcsolat értéke. Ugyanakkor a globális vállalatokon keresztül termékeik, kutatási eredményeik kike- rülnek a világpiacra, mellyel tetemes marketing-és piac építési ráfordításoktól mentesülnek. Ezek összege azonban inkább csak becsléssel közelíthető.

\section{,Valódi érték" felé \\ Az értékdimenzió kiterjesztése}

Az érték primer felmerülési terepe a piac. A vevőktől befolyó árbevételből számított szabad pénzáramlásra, befektetett tőke hozamára, gazdasági profitra stb. mint hagyományos értékmérőkre tekintünk.

A folyamat fókuszát az a piaci szegmens alkotja, melyből szabad cash-flow származik. A vállalat termékeit, szolgáltatásait viszont speciális, magas szinten képzett, kreatív emberek, munkatársak állítják elő, a vállalatvezetés „karmesteri” tevékenysége mellett. A vállalati értékmodell több okból kifolyólag is megérett az újragondolásra.

- A társadalom egyre nagyobb rétegeiben növekszik a környezet és társadalomtudatos életszemlélet és ezen társadalom egy része vevőként pénztárcájával, más része munkatársként/vezetőként szabad vállalat választásával, harmadik része pedig tulajdonosként tőkéjével szavaz társadalmilag is kívánatos tevékenységek folytatására.

„A tulajdonosi érték szemlélet és az érintett elmélet szembenállását azaz irányzat oldhatja fel, mely előbbi vitathatatlan elsóbbsége mellett teret enged más, társadalmilag kívánatos prioritások felvételé nek is" - állítja Alfred Rappaport. Ez a nézet már nem teljesen helytálló, csak addig lehetett kizárólagosan követendő elv, míg a profit egzakt tevékenységek, túlnyomórészt jól megbecsülhető outputjainak talaján állt, ami inkább az ipari társadalom sajátossága volt. A pozitív eredmény követelménye természetesen továbbra is kritérium marad, azonban nem feltétlenül a termék vagy vállalkozás, ,teljes élettartama" alatt. Jövőorinetált vállalatokról révén szó a bizonytalan időszak, nagy tőkeigény és kétes kimenetelű eredmény ingoványos befektetői talajt képez.

- Meglátásom szerint az új típusú gazdaság vállalatainak tevékenysége egyszerre teremti meg a tulajdonosok és érintettek értékharmóniáját. Gondoljunk csak egy ígéretes génkutatásra, melynek eredménye több halálos betegség ellenszeréül szolgálhat majd. Feltételezve a megfelelő termék kibocsátását, a vásárlói szándék - hasonló profilú versenytársak mellett is - (az ár-megfontoláson túl) a környezettudatosabb vagy társadalmilag érzékenyebb müködést felmutató vállalat felé fordulhat. Az egyre inkább független, szabadúszó kutatók, tanács- 
adók hasonlóan cselekedhetnek, munka/megbízási szerződésüket új vállalattal kötik meg. Nem értek egyet például azon véleménnyel, miszerint a nagy szakértelemmel rendelkező munkatársak által kifejlesztett egyedi és vállalatspecifikus tudás miatt a jelenlegi vállalatnak teremtett többletérték más szervezetnél kevesebbet ér (Rappaport, 2002). Pontosan napjaink egyre kiélezettebb versenye, azon belül is az innovatív, húzóágazatokban tapasztalható gyors alkalmazkodás és a követő stratégiát folytató vállalati magatartás miatt igen értékes lehet egy szoftvermérnök a versenytárs, vagy egy újonnan alakuló társaság számára, még ha jövedelme esetlegesen néhány év múlva emelkedik csak újra - de akkor exponenciálisan -, és ezzel együtt belépésekor kapott esetleges részesedése is átértékelődik. Nem elfogadható érvelés, miszerint „Valószínütlen, hogy ezek az alkalmazottak olyan helyen találnak munkát, amely a jelenlegivel megegyezö jövedelmet fizetne." 19 Ugyanakkor az idézett szerző elismeri, hogy a kulcsalkalmazottak által kifejlesztett termékek, szolgáltatások válnak egyre inkább a kritikus értékhordozók forrásává. A korábban taglalt munkaerő-piaci tendenciák is inkább az előbbi érvelést gyengítik.

- Megfontolandó továbbá, hogy az amerikai gazdaság elaprózott tulajdonosi szerkezetéből következően, hány millió kisbefektetô (család) gyakorolhat nyomást egyszerre közvetlenül vagy közvetve eladási megbízást adva adott vállalati részvényre? Közismert a modern tőkepiacok intézményi befektetők (nyugdíj,- egészségbiztosítási és egyéb befektetési alapok) általi befolyásoltsága. Az USA ezer legnagyobb vállalatának 57\%-át, teljes részvénypiacának 47,5\%-át tartják kezükben. (Rappaport, 2002) Fentiek alapján ,érdekes” következtetés, hogy a tulajdonosi érték szemlélet követése éppen a ,mi”, (kisbefektetők) tulajdonossá válásunk miatt válik" kényszerítő erejüvé"20.

- A lágy faktorok mint etika, környezet- és társadalomtudatosság, melyek többek véleményével szemben nem zilálják szét a gazdasági racionalitást, nem csökkentik a jövedelmezőséget, megkárosítva ezzel a befektetőket, és nem ássák alá a gazdasági rendszer alapjait sem. Az ctikai tôzsdeindexek korában adatokkal is alátámasztható, hogy etikai alapok legalább olyan kiemelkedő hozamokat, több esetben pedig jobbat érnek el, mint társaik. A környezeti és társadalmi értékeket működésük során szem előtt tartó vállalatok részvényei tartósan jó eredményeket mutatnak.

- Bizonyos társadalmi tevékenységek vállalati szférába emelése igenis kedvezően befolyásolja mind a termelékenységet, mind a kreativitást. Ez utóbbi pe- dig kiemelkedő jelentőségű kulcsa a szellemi tőke serkentésének. Az átlátható tevékenység, a szélesebb körű nyilvánosságra hozatal tehát indokolt kezdeményezés a szabályozó hatóságok részéről, jóllehet a piac örökké való láthatatlan keze automatikus szelekciót valósít meg a jövőben is. Meglepő módon éppen a versenyszellem legerősebb képviselője, az Egyesült Államok jár az élen bizonyos társadalmi érdekű, nonprofit tevékenységek, mint nyugdíj és egészségbiztosítás vállalati felelősségi körbe delegálásával, megteremtve ezzel a ,gondoskodó-vállalat" típusát. Európában az EU bizottsága 2003-ban határozta el az Európa Parlament Ipari Bizottságának jelentése nyomán, hogy három éven belül szülessen direktívatervezet a vállalatok társadalmi felelősségéről.

\section{A vállalatok felelősségének az Európai}

Bizottság által erősíteni javasolt területei ${ }^{21}$

- Az alkalmazottakkal való együttműködés és konzultáció az elbocsátások, átszervezések idején.

- Az élethosszig tartó tanulás, az egészség és biztonság, a munka és a szabadidő közötti egyensúly, a nemek közötti egyenlőség a fizetés és az előmeneteli lehetőség tekintetében, a profitmegosztás és az alkalmazottak vállalati részesedése.

- A helyi közösségekkel ápolt kapcsolatok, a kezdő illetve kis- és középvállalkozások támogatása.

- A termékek „hatékony és etikus” eljuttatása a fogyasztókhoz.

- Az alvállalkozókkal és szállítókkal kötött szerződések során irányelvek megfogalmazása a munkakörülmények, az emberi jogok és a környezetvédelem szempontjainak érvényesitése.

- A végrehajtás során nagyobb átláthatóság, jobb felügyelet.

- Konszenzus arról, hogy a vállalatoktól mely információk nyilvánosságra hozatalát követeljék meg, illetve átfogóbb szabályozás a szociális jelentésekről, elszámoltatásról és vizsgálatokról.

- A termékeket etikai szempontból minősito" címkézés elterjesztése és lehetőségeinek jobb kihasználása, hatékonyságának növelése igazolási mechanizmusok kialakításával.

- A finanszírozás során a szociális kritériumoknak megfelelő vállalatokat előnyben részesítő, ,szociálisan felelős beruházás" előmozdítása a társadalmi jelentések rendszerének egységesítésével és az értékelési szempontok harmonizációjával.

$\mathrm{Az}$ 1. ábra az értékszemlélet egy kifinomultabb rendszerét kívánja szemléltetni. 
Kiterjesztett modell: ,Valódi érték- modell”

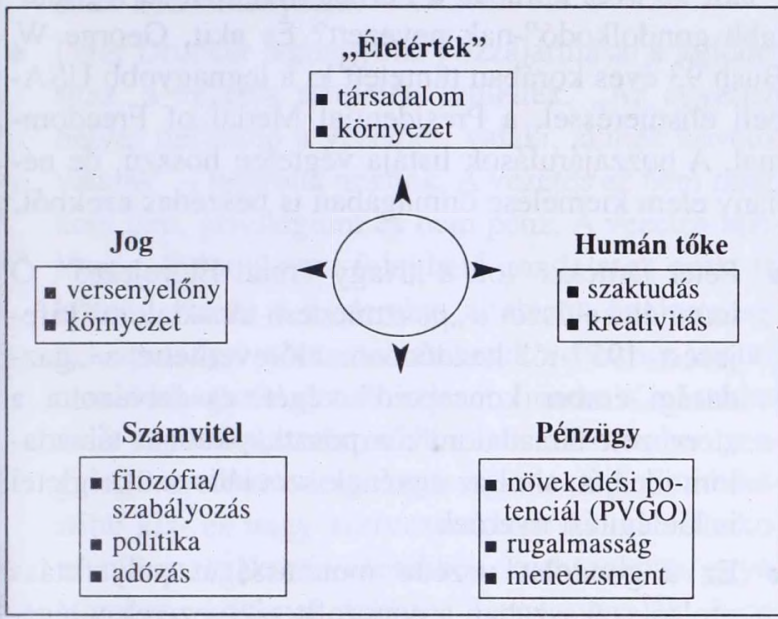

Számvitel: a nagy pontossággal rögzített múltbeli tevékenység tükre a vezetők és a nyilvánosság számára. Értéke: transzparens, tiszta beszámolók

Hátránya: múltorientált

Pénzügy(i) (piacok): dinamikus, jövőorientált értékelést valósít(anak) meg, az árfolyamok időszakos torzításai mellett.

Értéke: opciók révén egyidőben, többdimenziós értékelés

Hátrány: ingadozás (volatilitás)

Jog: biztos általános jogi környezet, a változásokat rugalmasan követő jogalkotás. Kiemelten fontos az új vállalatok szellemi termékeinek jogvédelmében.

Értéke: perek költségek és idő ráfordításainak megelőzése

Hátrány: nehézkes

Humán tőke: a tudásalapú gazdaság abszolút elsőbbséget élvező erőforrása, értékhordozója (value driver) vállalati és fogyasztói oldalon egyaránt

\section{Felhasznált irodalom}

Brealey, R. A. - Myers, S. (1999): Modern vállalati pénzügyek I-II, Panem, Budapest

Business Week: Nasty Surprises -Suddenly, the Continent is awash in accounting scandals, 2003. március 10.

Copeland, T. - Koller, T. - Murrin, J. (1999): Vállalatértékelés, Panem, Budapest

Figyelő Trend: A XXI. század vállalata, 2001/3.

Juhász Péter (2005): Az üzleti kapcsolatok pénzügyi értékelési lehetôségei, Vezetéstudomány, 5. sz. (35.-43. o.)

Matesz Béla (2003): Az Enron-csőd egy éve, Bank és Tôzsde, február

Mészáros Tamás (2002): A stratégia jövôje - a jövô stratégiája, Aula, Budapest portfolio.hu:

Új nap alatt a tőkepiaci perek? 2004. június 22.

A botrány utóhatása, 2005. augusztus 17 .

Adóbotrány a KPMG-nél, 2005. augusztus 30.

Rappaport, A. (2002): A tulajdonosi érték, Aline, Budapest

Világgazdaság: Az it-boom Európában csak mítosz volt, 2003. március 5 .

A vállalatok felelőssége, 2003. február 5.

Az Andersen nyílt levele, 2002. október 10.

www.graphisotf.hu

\section{Lábjegyzetek}

1 A tudósvállalatok értékelési sajátosságai I. című TDK dolgozat a jelenség számviteli dimenzióit taglalja. (Nagy Péter, BKÁE, Számvitel tanszék, 2003)

2 Mészáros Tamás (2003): A stratégia jövője- a jövő stratégiája Aula

3 Világgazdaság, 2003. március 5.

4 Figyelő Trend 2001/3 (6. o.)

5 Technológia alatt a tudásintenzív iparágak elsősorban az információtechnológiát, de más húzóágazatok, mint pl. gyógyászat, bio- és nanotechnológia stb. tevékenységeit is értem.

6 Brealey-Myers: Modern Vállalati pénzügyek I. (124-132. o.)

7 A Graphisoft áttörése a világpiacon, www.graphisoft.hu

8 Részlet az Andersen nyílt leveléből: Világgazdaság 2002. október 10 .

9 Brealey-Myers i.m. (112. o.)

10 Miután napvilágot látott, hogy az Andersen milyen szerepet töltött be az Enron könyvelési csalásainál, akadályozva az igazságszolgáltatást, a vezérigazgató - a nyilvánosság tájékoztatására - nyílt levélben tette közzé álláspontját és az eszközölt lépéseket a Wall Street Journal hasábjain, de a folyamatot már nem lehetett visszafordítani és a Big 5 egyike megszűnt létezni.

11 portfolio.hu internetes üzleti napilap: A botrány utóhatása, 2005. augusztus 17 .

12 portfolio.hu: Adóbotrány a KPMG-nél, 2005. augusztus 30

$13 \mathrm{Az}$ ennek következtében fellépố szabályozási igény magyar vonatkozása, hogy az Igazságügyi Minisztérium komplex szabályozást tervezett 2004-ben a társasági jogi és a tôkepiaci perek elbírálására. A jövőben a társasági jogi, tőkepiaci és pénzügyi szolgáltatásokra vonatkozó jogvitákból önálló, az általánostól eltérô pertípust alkotnak. Az új szabályozás felgyorsítja a céleljárásokat, melyek közé többek között a konszernjogi perek, a részvényesi osztálykeresetek, az értékpapírjogi, illetve könyvvizsgálói jogviták is tartoznának. (Portfólió.hu: Új nap alatt a tőkepiaci perek, 2004. június 22.)

14 Pontosabban, a szintén nem újdonság bennfentes kereskedelem szigorú üldözése már sejtetni engedte, hogy valami „nem jól múködik a világban”. Az etika jogi eszközökkel való körbebástyázása egyébként is gyenge hatásfokú, adott társadalom politikai és általános kulturális szintjének is erős függvénye.

15 A több mint két évig tartó bírósági ügy 2003. januárjában lezárult, azzal a megállapodással, hogy mindkét fél tartózkodik olyan, viszonteladóik, vevőik és a nyilvánosság felé tett nyilatkozatoktól, melyek a másik félre nézve hátrányos tartalmúak.

16 Option Pricing Model.

17 Brealey-Myers, i.m. II. rész (109-122. o.)

18 Juhász Péter: Az üzleti kapcsolatok pénzügyi értékelési lehetốségei, Vezetéstudomány, 2005. 5. szám (38-42. o.)

19 Alfred Rappaport, A tulajdonosi érték Alinea 2002 (24. o.)

20 Rappaport i.m. (25. o.)

21 Világgazdaság, 2003. február 5. (Kiemelések tőlem: N. P.) 